Penelitian

\title{
Isolasi dan Identifikasi Aspergillus Sp. pada Kantung Hawa Puyuh (Cortunix Japonica)
}

\author{
Isolation and Identification of Aspergillus Sp. from \\ Air Sac of Quail (Cortunix japonica) \\ Mega Cempaka Putri', Erina ${ }^{2 *}$, Mahdi Abrar ${ }^{2}$, M. Daud AK ${ }^{2}$ \\ ${ }^{1}$ Program Studi Pendidikan Dokter Hewan Fakultas Kedokteran Hewan Universitas Syiah Kuala \\ ${ }^{2}$ Laboratorium Mikrobiologi Fakultas Kedokteran Hewan Universitas Syiah Kuala \\ *Penulis untuk korespondensi: erina@unsyiah.ac.id \\ Diterima 17 Februari 2021, Disetujui 20 Mei 2021
}

\begin{abstract}
ABSTRAK
Aspergillosis merupakan penyakit yang disebabkan oleh jamur Aspergillus sp. yang dapat menyerang puyuh muda secara akut dan sebagai penyakit menahun pada puyuh dewasa. Penelitian ini bertujuan untuk mengisolasi dan mengidentifikasi Aspergillus sp. pada kantung hawa puyuh (Coturnix japonica). Sampel yang digunakan dalam penelitian ini adalah 35 kantung hawa puyuh yang tidak produktif lagi (afkir) diambil secara acak. Isolasi dan identifikasi Aspergillus sp. dilakukan sesuai dengan menggunakan metode Thompson. Sampel dicuci dengan aquadest steril berisi antibiotic gentamicin selanjutnya ditanamkan pada media Sabouraud's Dextrose Agar (SDA) kemudian diinkubasikan pada suhu kamar selama 3-7 hari. Pertumbuhan koloni Aspergillus sp. diamati morfologinya secara makroskopis dan mikroskopis. Data yang diperoleh dianalisis secara deskriptif. Hasil pemeriksaan menunjukkan bahwa Aspergillus sp. dapat diisolasi dan diidentifikasi pada 24 dari 35 sampel kantung hawa. Berdasarkan hasil penelitian dapat disimpulkan bahwa $68,57 \%$ sampel yang diperiksa positif terinfeksi Aspergillus sp. dengan persentase masing-masing spesies Aspergillus fumigatus 40\%, Aspergillus flavus 25,7\%, dan Aspergillus niger 17,1\%.
\end{abstract}

Kata kunci: Aspergillus sp., kantung hawa, puyuh (Cortunix japonica), zoonosis

\begin{abstract}
Aspergillosis is a disease caused by Aspergillus sp which can cause disease as chronic or acute infection. The aim of this study is to isolate and to identify Aspergillus sp. from air sac of the quails. The samples used in study were 35 pairs of air sac from unproductive (culling) quails taken randomly. This study was conducted as field observational and experimental laboratory based on Thompson's method. The samples were washed in sterile aquadest containing antibiotic $0,1 / 100 \mathrm{ml}$ diluent. Then, it cultured on Saboraud's Dextrose Agar (SDA) followed by incubated at room temperature for 3-7 days. The samples were observed every 24 hours for macroscopically and microscopically identification. Data were analysed descriptively. The result of this study showed that Aspergillus sp. can be isolated and identified from 24 out of 35 pairs of air sac $(68,57 \%)$. It can be concluded that air sac of the quails are infected by Aspergillus sp. The percentage of each species of Aspergillus is as the following: Aspergillus fumigatus, Aspergillus flavus and Aspergillus niger.
\end{abstract}

Keywords: Aspergillus sp., air sac, invasive fungi, quail (Cortunix japonica), zoonotic disease 


\section{PENDAHULUAN}

Pada awalnya burung puyuh adalah burung liar namun dari semua kelompok burung puyuh liar tersebut, ternyata hanya spesies Cortunix cortunix yang berhasil dijinakkan (Wheindrata, 2014). Sekitar tahun 1870 puyuh pertama kali didomestikasi atau diternakan di Amerika untuk diambil produksi telur dan dagingnya. Namun oleh National Institute of Genetic, puyuh untuk pertama kalinya diternakkan sebagai burung aduan di Jepang dan begitu pula di Indonesia. Kemudian pemerintah menunjang alternatif penyediaan protein hewani masyarakat, lalu puyuh diternakkan secara komersial (Destia et al., 2017).

Puyuh tidak jarang digunakan sebagai hewan coba dalam berbagai penelitian karena daya tahan tubuhnya cukup baik, tahan dengan berbagai penyakit, juga memiliki daya pemulihan yang relatif tinggi. Secara umum pertumbuhan tidak hanya dipengaruhi oleh konsumsi pakan, namun pengaruh growth hormon yang dieksresikan juga mempengaruhi pertumbuhan unggas. Namun demikian, tidak menutup kemungkinan bahwa puyuh dapat terserang berbagai penyakit salah satunya yaitu Aspergillosis (Susilorini, 2007).

Kasus Aspergillosis pada berbagai jenis unggas baik yang diternakkan, ataupun yang hidup bebas sering bergantung pada jenis pakan yang dikonsumsi. Pada umumnya jenis burung atau unggas pemakan bebijian (serelia) lebih sering menderita penyakit aspergillosis jika dibandingkan dengan jenis burung lain yang bukan pemakan bebijian, karena bebijian tersebut dapat dipaparkan atau dicemari oleh berbagai jenis jamur terutama Aspergillus sp. (Maryam, 2006).

Informasi mengenai kapang Aspergillus sp. pertama kalinya dari lesi burung liar pada tahun 1800-an (Sauza et al., 2005). Dilaporkan kejadian infeksi Aspergillus sp. menyerang hampir semua spesies unggas yang dipelihara dan beberapa jenis unggas produksi seperti ayam petelur (Throne et al., 2003). Namun tidak jarang pula menyerang pada burung unta, ayam kalkun, merpati dan burung puyuh (Tokarzewski et al., 2007). Penelitian terkait isolasi Aspergillus sp. telah dilakukan oleh Natasha (2018), peneliti telah mengisolasi paru-paru puyuh dengan hasil dari 30 pasang sampel paru-paru puyuh (Coturnix japonica) sebanyak 26 sampel (86,67\%) dinyatakan dapat diisolasi Aspergillus sp.

Ada 250 spesies Aspergillus di dunia, namun hanya 10 spesies yang berbahaya. Salah satunya yaitu $A$. flavus yang mendudukin peringkat kelima dari tingkat virulensinya karena $A$. flavus mampu bertahan hidup dalam kondisi iklim panas dan kering, juga mampu bermanifestasi dalam berbagai bentuk. Infeksi yang disebabkan oleh $A$. flavus ini dominan pada daerah Asia, Timur Tengah dan Afrika (Shivaprakash et al., 2019).

Kantung hawa (Sacci pneumatica) pada puyuh berbeda dengan hewan mamalia. Unggas memiliki 4 pasang kantung hawa yang letaknya antara leher sampai dinding perut satu kantung median dalam rongga dada. Kantung ini membuka ke dalam paru dan berhubungan dengan tulang pneumatic. Kantung hawa terdiri atas suatu rongga dengan dinding jaringan yang tipis dan halus sehingga sulit dikenali sewaktu dalam posisi mengempis. Selain sifatnya yang halus, kantung hawa ini mempunyai suasana yang lembab sehingga dapat dengan mudah terpaparnya jamur yang hidup dan berkembang ditempat yang lembab (Akoso, 1998).

Menurut hasil survey kepeternakan puyuh, puyuh yang tidak produktif lagi dipotong dan selanjutnya dijual ke pasar tani sebagai bahan konsumsi alternatif protein hewani. Apabila puyuh tersebut dikonsumsi oleh anak-anak, orang lanjut usia dan orang yang immunosupresif, maka akan berpotensi untuk terserang jamur Aspergillus sp. (Aspergillosis). Berdasarkan permasalahan diatas, maka perlu dilakukan penelitian tentang Isolasi dan Identifikasi Aspergillus sp. pada Kantung Hawa Puyuh (Cortunix japonica).

\section{BAHAN DAN METODE}

\section{Tempat dan Waktu Penelitian}

Kegiatan penelitian ini dilaksanakan di Laboratorium Mikrobiologi Fakultas Kedokteran Hewan Universitas Syiah Kuala Banda Aceh, pada bulan Oktober 2019.

\section{Sampel Penelitian}

Sampel penelitian yang digunakan adalah 35 kantung hawa puyuh yang diculling di peternakan puyuh Hanin Group Desa Lam Bheu Kecamatan Darul Imarah, Aceh Besar.

\section{Alat dan Bahan Penelitian}

Alat-alat yang digunakan dalam penelitian ini yaitu cawan petri steril, tabung reaksi, rak tabung, erlenmeyer, spuit, kertas label, ose, lampu spritus, scalpel, pisau, gunting, kapas, pipet, object glass dan mikroskop. Bahan yang digunakan dalam penelitian ini adalah aquadest steril, antibiotik gentamisin, media Sabourauds Dextrose Agar (SDA) dan Lactophenol Cotton Blue (LCB). 


\section{Metode Penelitian}

Penelitian ini adalah penelitian deskriptif dengan menggunakan metode Thompson (1969). Aspergillus sp. diisolasi dengan cara membiakkan kantung hawa puyuh ke dalam medium Sabouraud Dextrose Agar (SDA) dan diinkubasikan pada suhu kamar selama 3-7 hari. Selanjutnya biakan diamati setiap hari untuk mengamati pertumbuhan koloni jamur secara makroskopis dengan melihat warna koloni jamur dan bentuk permukaan bawah tepi koloni. Untuk mengidentifikasi jamur dibuat slide kultur dan diamati secara mikroskopis.

\section{Prosedur Penelitian}

\section{Pengambilan sampel}

Sampel yang digunakan adalah kantung hawa dari 35 ekor puyuh yang diculling diambil secara acak dari peternakan puyuh di Desa Lam Bheu Kecamatan Darul Imarah, Aceh Besar. Kantung hawa puyuh tersebut diambil secara aseptik dari peternak dan ditempatkan dalam plastik, kemudian dibawa ke Laboratorium Mikrobiologi Fakultas Kedokteran Hewan Universitas Syiah Kuala.

\section{Isolasi jamur Aspergillus sp.}

Sampel diambil secara aseptik dimasukkan ke dalam cawan petri steril, dengan menggunakan gunting kantung hawa dipotong dengan ukuran kira-kira $1 \mathrm{~cm}$, potongan kantung hawa tersebut dicuci sebanyak $3 x$ dengan aquades steril yang berisi antibiotik gentamisin $(0,1 \mathrm{cc} / 100 \mathrm{ml})$, Selanjutnya tiap potongan kantung hawa ditanamkan ke permukaan media Sabouraud Dextrose Agar (SDA) dan diinkubasikan pada suhu kamar selama 3-7 hari. Pada hari ke-2 dan seterusnya biakan diamati terhadap pertumbuhan koloni jamur secara makroskopik yaitu dengan melihat bentuk, warna, permukaan bawah dan tepi koloni.

Identifikasi jamur Aspergillus sp.

Untuk mengidentifikasi jamur yang diduga Aspergillus sp maka dilakukan penanaman pada slide kultur. Slide kultur dibuat dengan cara meletakkan pipet steril pada dasar cawan petri, kemudian ditempatkan kapas yang telah dibasahi dengan aquades steril pada cawan petri tersebut, sehingga suasana didalam cawan petri menjadi lembab. Selanjutnya diletakkan objek glass diatas pipet, Sabouraud Dextrose Agar (SDA) dipotong dengan ukuran $1 \times 1 \mathrm{~cm}$ diletakkan di atas objek glass. Kemudian dioleskan potongan SDA dengan dibiakan jamur pada empat sisi dengan menggunakan ose steril. Potongan agar ditutup kembali. Biakan diinkubasikan pada suhu kamar selama 3-7 hari. Selanjutnya koloni diwarnai dengan meneteskan Lacophenol Cotton Blue (LCB) pada pinggiran cover glass dan diidentifikasi dibawah mikroskop pada pembesaran 400x.

Analisis data

Data hasil penelitian yang diperoleh dianalisis secara deskriptif dan disajikan dalam bentuk tabel dan gambar.

\section{HASIL DAN PEMBAHASAN}

Dari hasil pemeriksaan terhadap kantung hawa puyuh yang terindikasi positif Aspergillus sp. terdapat penebalan membran selaput dinding kantung hawa, namun tidak dengan penemuan plak atau nodul putih kekuningan seperti yang telah disampaikan oleh Beernaert et al., (2010) bahwa plak atau nodul putih kekuningan biasanya terlihat pada kantung hawa yang terinfeksi oleh Aspergillus sp. serta terdapat penebalan membran selaput kantung hawa.

Aspergillus sp. pada media SDA setelah pengamatan 24 jam (Gambar 1a) menunjukkan pertumbuhannya setelah diisolasi berwarna putih granul disekitar permukaan sampel. Setelah warna putih bergranul memenuhi permukaan sampel, pengamatan saat 72 jam (Gambar 1b) maka akan muncul warna yang beragam sesuai spesies dari Aspergillus sp. Pada pengamatan sampel saat 96 jam (Gambar 1C) akan terlihat warna koloni jamur yang semakin jelas sesuai spesiesnya. Selanjutnya dipengamatan saat 120 jam (Gambar 1d) warna-warna tersebut tampak menyebar memenuhi media yang dapat dilihat pada Gambar 1.

Normalnya kantung hawa mempunyai selaput dinding yang tipis dan bersih. Ketersediaan udara dan saluran pernapasan yang bersih merupakan syarat utama agar sistem pernapasan berfungsi dengan baik (Saminan, 2016). Hal tersebut tidak demikian pada sebagian kantung hawa yang telah diteliti. Sebagian sampel kantung hawa yang diperiksa masih terlihat normal, baik warna maupun konsistensinya.

Hasil isolasi Aspergillus sp. pada 35 sampel kantung hawa puyuh berdasarkan pengamatan secara makroskopis menunjukkan 34 positif adanya pertumbuhan jamur dengan pertumbuhan positif Aspergillus sebanyak 24 sampel dan 10 dinyatakan non Aspergillus serta satu diantaranya adalah negative atau dengan kata lain tidak adanya pertumbuhan 
(A)

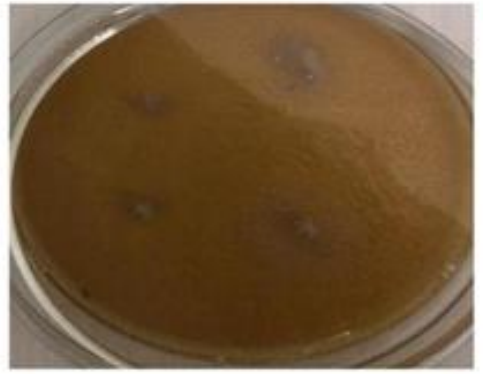

(C)

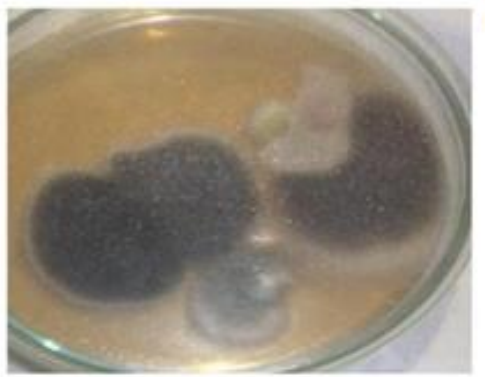

(B)

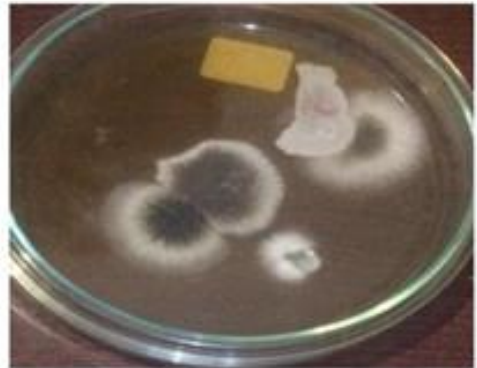

(D)

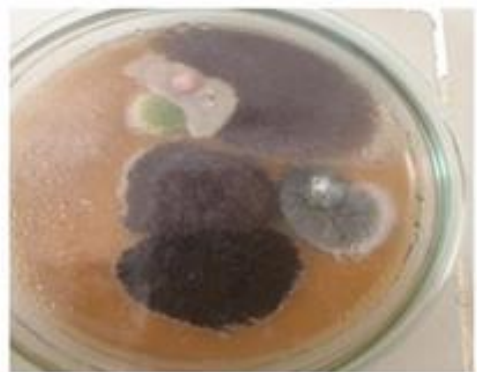

Gambar 1 Pertumbuhan jamur Aspergillus sp. yang tumbuh pada media Sabouraud's Dextrose Agar (SDA): (a) waktu 24 jam, (b) waktu 72 jam, (c) waktu 96 jam, (d) waktu 120 jam

jamur. Hasil pengamatan secara makroskopis dari isolasi Aspergillus sp. terhadap 35 sampel kantung hawa puyuh dapat dilihat pada Tabel 1.

Pertumbuhan koloni Aspergillus sp. akan optimal pada suhu kamar. Hal ini ditegaskan oleh (Naim, 2016) bahwa dengan subur Aspergillus sp. akan tumbuh pada rentang suhu $25^{\circ} \mathrm{C}-30^{\circ} \mathrm{C}$ dalam kelembaban udara $80-85 \%$ dan material media umum pertumbuhan. $\mathrm{pH}$ yang rendah $(5,6 \pm 2)$ merupakan salah satu faktor yang akan menghambat pertumbuhan bakteri sehingga mendukung pertumbuhan jamur.

Pengamatan hasil identifikasi dengan penanaman pada slide culture dan pewarnaan menggunakan Lactophenol Cotton Blue (LCB) secara mikroskopis yaitu sebagian jamur yang tumbuh pada sampel kantung hawa serasi dengan Tabel 1 yaitu benar bahwa spesies tersebut merupakan Aspergillus sp. dan diidentifikasi secara makroskopis kemudian disinkronkan dengan warna koloni jamur yang tumbuh pada media SDA maka diketahui ada 3 jenis Aspergillus yang ditemukan yaitu Aspergillus fumigatus, Asprgillus flavus dan Aspergillus niger. Hal ini juga sesuai dengan pernyataan Hasanah (2017) bahwa Aspergillus fumigatus dan Aspergillus niger merupakan penyebab infeksi opurtunistik yang paling sering terjadi pada organ pernapasan.
Sementara beberapa sampel yang telah diperiksa terdapat multipel infeksi oleh Aspergillus sp. misalnya pada sampel AS3, AS4, AS6, AS14 dan AS18 yang dapat dilihat pada Tabel 2 terdapat dua hingga tiga spesies Aspergillus dalam satu cawan. Menurut Brooks et al., (2013) koloni Aspergillus flavus berwarna hijau kekuningan dengan pinggiran berwarna putih dan Aspergillus fumigatus berwarna hijau sampai hijau tua dengan pinggiran berwarna putih.

Untuk mengidentifikasi spesies Aspergillus secara mikroskopis karakteristiknya meliputi bentuk dari kepala konidia, bentuk vesikel dan diameter, ukuran konidia, tekstur serta warna. Hasil isolasi menunjukkan karakteristik yang berbeda-beda (Tabel 2). Hasil pengamatan ini sesuai dengan penelitian yang telah dilakukan oleh Nyongesa et al. (2015) bahwa morfologi secara makroskopik yang dapat diamati dari spesies Aspergillus sp. yaitu tekstur dari koloni dan pigmentasinya, warna dibalik koloni, formasi sklerotia yang terdiri dari exudate drops, radial furrow dan growing zone.

Hasil konfirmasi dari isolat nomor kode AS8 yang tumbuh pada umur 96 jam menunjukkan warna koloni hijau kekuningan dengan miselium warna kuning cokelat ditepi dan bergranular dibagian tengah koloni. Disamping itu growing zone juga didapatkan 
serta warna dibalik koloni. Hal tersebut dicocokan dengan hasil penelitian Gandi et al. (2019) bahwa koloni bewarna hijau kekuningan dengan tepi kuning hingga cokelat ini selain mempunyai tekstur granular juga mempunyai permukaan yang halus seperti beludru.

Pertambahan dari volume sel tersebut merupakan irreversible yang artinya volume sel tidak dapat kembali ke volume semula. Praja dan Yudhana (2017) mengungkapkan bahwa koloni Aspergillus sp. pada umumnya berwarna putih terang dengan miselium seperti kapas. Mula-mula koloni muncul dengan filamen putih dan akan berubah warna sesuai spesiesnya. Tanda spesifik lain dari koloni ini yaitu ditandai dengan konidia yang cepat menyebar. Terdapat tiga spesies Aspergillus yang ditemukan pada penelitian ini, yaitu Aspergillus niger yang ditunjukkan dengan warna miselium yang berwarna hitam, dan Aspergillus fumigatus yang ditunjukkan dengan miselium berwarna putih kehijauan sampai hijau tua dan Aspergillus flavus yang ditunjukkan dengan warna mislium hijau kekuning-kuningan. Pertumbuhan dan perubahan warna koloni dari Aspergillus fumigatus, Aspergillus niger dan Aspergillus flavus dapat dilihat pada Gambar 2. Pengamatan ini sesuai dengan hasil pengamatan yang dilakukan oleh
Gandjar (2006) bahwa parameter yang dapat diamati dari pertumbuhan suatu koloni Aspergillus sp adalah bertambahnya volume sel dikarenakan adanya pertambahan senyawa asam nukleat dan protoplasma.

Dalam penelitian ini selain permukaannya berwarna kekuningan, bagian bawah Aspergillus flavus juga terlihat kekuningan hingga cokelat. Seperti yang telah dilaporkan oleh Krishnan et al. (2009) secara makroskopis Aspergillus flavus pada mulanya memiliki permukaan berwarna kuning tetapi seiring bertambahnya usia, karakteristik warnanya berubah menjadi hijau kekuning-kuningan .

Pada media SDA koloni Aspergillus niger pada mulanya berwarna putih pada titik suhu dan waktu yang tepat, koloni ini berubah warna menjadi hitam dengan sedikit pinggiran putih dan permukaan bawah koloni berwarna kecoklatan. Seperti yang dideskripsikan oleh Ade (2013) jenis ini mempunyai karakteristik yang khas yaitu adanya lapisan konidiofor yang rapat dan padat berwarna coklat gelap sampai hitam.

Dari ciri makroskopis koloni Aspergillus fumigatus pada mulanya muncul dari kumpulan seprti beludru putih yang selanjutnya berubah warna menjadi hijau sampai hijau tua dengan pinggiran berwarna putih

Tabel 1 Hasil isolasi Aspergillus sp. pada 35 sampel kantung hawa puyuh berdasarkan pengamatan secara makroskopis

\begin{tabular}{ccc}
\hline Sampel & $\begin{array}{c}\text { Pertumbuhan Jamur pada Me- } \\
\text { dia SDA }\end{array}$ & Jenis Jamur \\
\hline AS1 & + & Aspergillus sp. \\
AS2 & + & Aspergillus sp. \\
AS3 & + & Aspergillus sp. \\
AS4 & + & Aspergillus sp. \\
AS5 & + & Aspergillus sp. \\
AS6 & + & Aspergillus sp. \\
AS7 & + & Aspergillus sp. \\
AS8 & + & Aspergillus sp. \\
AS9 & + & Aspergillus sp. \\
AS10 & + & Aspergillus sp. \\
AS11 & + & Aspergillus sp. \\
AS12 & + & Aspergillus sp. \\
AS13 & + & non Aspergillus sp. \\
AS14 & + & Aspergillus sp. \\
AS15 & + & non Aspergillus sp. \\
AS16 & + & Aspergillus sp. \\
AS17 & + & non Aspergillus sp. \\
AS18 & + & Aspergillus sp. \\
AS19 & + & Aspergillus sp.
\end{tabular}




\begin{tabular}{ccc} 
AS20 & + & non Aspergillus sp. \\
AS21 & + & non Aspergillus sp. \\
AS22 & + & non Aspergillus sp. \\
AS23 & + & non Aspergillus sp. \\
AS24 & + & Aspergillus sp. \\
AS25 & + & Aspergillus sp. \\
AS26 & + & non Aspergillus sp. \\
AS27 & + & Aspergillus sp. \\
AS28 & + & Aspergillus sp. \\
AS29 & + & non Aspergillus sp. \\
AS30 & + & non Aspergillus sp. \\
AS31 & + & Aspergillus sp. \\
AS32 & + & Aspergillus sp. \\
AS33 & + & Aspergillus sp. \\
AS34 & - & - \\
AS35 & + & Aspergillus sp. \\
\multicolumn{3}{r}{} \\
& Jumlah (persentase positif & 35 \\
\end{tabular}

dan permukaan bawah koloni berwarna kekuningan hingga coklat. Ciri ini selaras dengan yang dilaporkan oleh Fathoni et al. (2007), bahwa koloni Aspergillus fumigatus yang tumbuh berwarna hijau pekat sampai keabuan ini mempunyai tepi koloni yang rata, tekstur seperti beludru dan datar.

Konfirmasi identitas isolat dilakukan dengan identifikasi secara mikroskopis dengan membiakan jamur pada slide culture dan melakukan pewarnaan menggunakan Lactophenol Cotton Blue untuk memperjelas pengamatan jamur secara mikroskopis. Dalam pemeriksaan mikroskopis terlihat adanya tonjolan vesikel di ujung konidiofor, fialid, hifa yang bersepta, dan konidia. Morfologi Aspergillus sp. secara mikroskopis dapat dilihat pada Gambar 5.

Pengamatan secara mikroskopis Aspergillus fumigatus terlihat ditandai pembentukan konidiofor dilengkapi tangkai konidiofor dengan kepala konidia terbentuk sebagai kolom yang terdiri atas vesikel berbentuk labu, fialid uniserate, dan rantai panjang konidia. menunjukkan adanya tangkai konidiofor, vesikel, dan konidia (spora) berbentuk bulat berwarna hijau kebiruan. Pengamatan ini dicocokan dengan hasil penelitian oleh Sugui et al. (2015) juga oleh Gholib dan Tarmudji (2005), bahwa pemeriksaan mikroskopis Aspergillus fumigatus menunjukkan
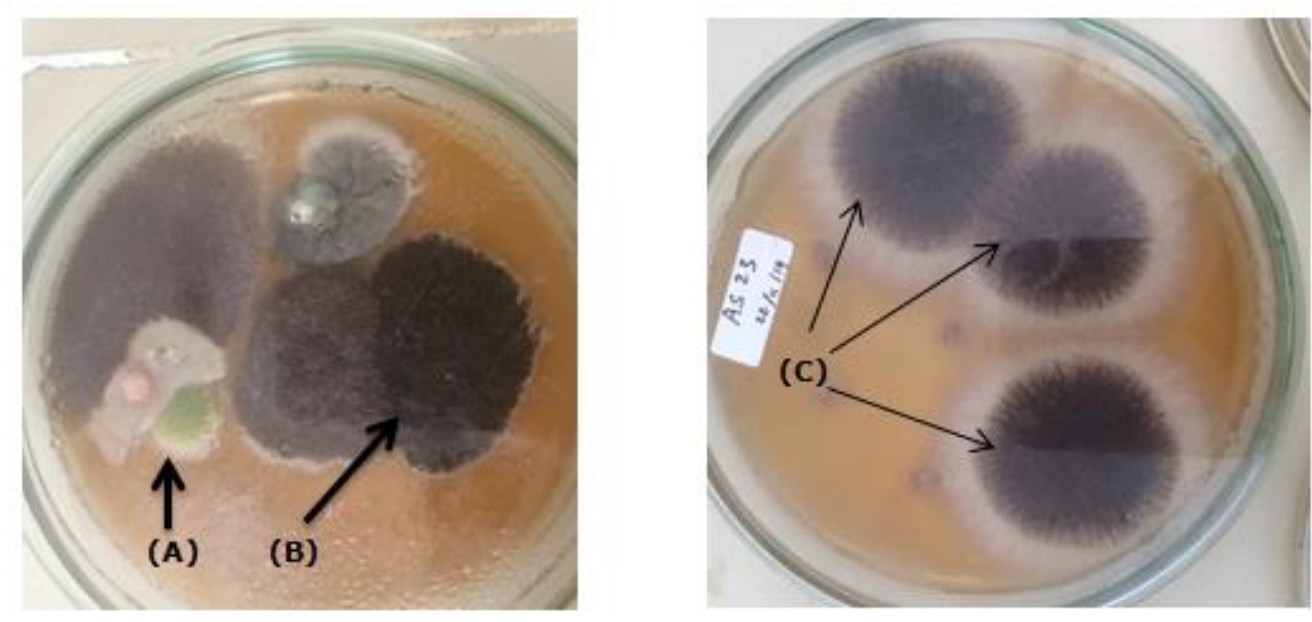

Gambar 2 Koloni Aspergillus sp yang tumbuh pada media biakan Sabouraud's Dextrose Agar waktu 120 jam. (A) Aspergillus flavus, (B) Aspergillus niger, (C) Aspergillus fumigatus 
adanya vesikel (kepala konidia) berbentuk oval (clavate) dan bulat, tangkai konidiofor yang pendek berwarna kehijauan serta akan berbentuk lonjong (columnar) dengan bertambahnya umur koloni. Diameter yang dimilikinya sebesar 2,5-3,5 mm. Fialid terlihat menutupi bagian atas vesikel namun hanya setengah bagian yang tertutupi. Spora konidia berbentuk bulat, berwarna kehijauan, dan permukaannya bergranul. Pengamatan Mikroskopis Aspergillus sp. disajikan pada Gambar 3.

Pengamatan mikroskopis terhadap Aspergillus niger dapat dicirikan pada warna konidia, fialid memenuhi seluruh permukaan vesikel dan vesikel globose (bulat) berukuran besar. Disesuaikan oleh pengamatan Wangge et al. (2012) bahwa Aspergillus niger berkoloni hitam dan pada bagian bawah koloni berwarna putih gradasi kuning. Pengamatan konidia terlihat bulat sampai semi bulat berwarna coklat serta pada pengamatan vesikel yang juga berbentuk bulat hingga semi bulat.

Hasil penelitian yang dapat diamati dari Aspergillus flavus ini bentuk kepala konidial tampak seperti globose atau bulat serupa dengan bola dan koloni terlihat serempak. Seperti yang telah disebutkan oleh Noviawati et al. (2018) bahwa koloni Aspergillus flavus secara mikroskopis memiliki konidiofor yang relatif panjang dan kasar. Kepala konidial bervariasimulai dari bentuk radial, kolom dan bola. Penelitian Krishnan et al. (2009) mengungkapkan terkait penelitian Aspergillus flavus bahwa perkecambahan konidia Aspergillus flavus terjadi sekitar 24 jam berbeda dengan spesies lainnya. Koloni ini relatif tumbuh lebih awal dibanding dengan koloni lainnya pada media SDA.

Berdasarkan hasil penelitian dapat disimpulkan bahwa 24 dari 35 sampel $(68,57 \%)$ kantung hawa puyuh (Coturnix japonica) yang diperiksa positif terinfeksi Aspergillus sp. dengan persentase setiap spesies Aspergillus fumigatus 40\%, Aspergillus flavus 25,7\%, dan Aspergillus niger 17,1\%.

"Penulis menyatakan tidak ada konflik kepentingan dengan pihak-pihak yang terkait dalam penelitian ini".

Tabel 2 Hasil identifikasi Aspergillus sp. pada 35 sampel kantung hawa puyuh

\begin{tabular}{lll}
\hline Sampel & \multicolumn{1}{c}{ Warna Koloni } & \multicolumn{1}{c}{ Spesies Aspergillus } \\
\hline AS1 & Hijau kekuningan & A. flavus \\
AS2 & Hitam & A. niger \\
AS3 & Hijau pekat, Hitam & A. fumigatus, A. niger \\
AS4 & Hitam, Hijau kekuningan, Hijau pekat & A. niger, A. flavus, A. fumigatus \\
AS5 & Hijau pekat & A. fumigatus \\
AS6 & Hijau pekat, Hijau kekuningan & A. fumigatus, A. flavus \\
AS7 & Hijau pekat & A. fumigatus \\
AS8 & Hijau kekuningan & A. flavus \\
AS9 & Hijau pekat & A. fumigatus \\
AS10 & Hijau kekuningan & A. flavus \\
AS11 & Hijau pekat & A. fumigatus \\
AS12 & Hijau kekuningan & A. flavus \\
AS13 & - & - \\
AS14 & Hitam, Hijau kekuningan & A. niger, A. flavus \\
AS15 & - & - \\
AS16 & Hijau pekat & A. fumigatus \\
AS17 & - & - \\
AS18 & Hijau kekuningan, Hijau pekat & A. flavus, A. fumigatus \\
AS19 & Hijau kekuningan & A. flavus \\
AS20 & - & - \\
AS21 & - & - \\
AS22 & - & - \\
- & & \\
& &
\end{tabular}




$\begin{array}{lll}\text { AS23 } & - & - \\ \text { AS24 } & \text { Hijau kekuningan } & \text { A. flavus } \\ \text { AS25 } & \text { Hitam } & \text { A. niger } \\ \text { AS26 } & - & - \\ \text { AS27 } & \text { Hijau kekuningan } & \text { A. flavus } \\ \text { AS28 } & \text { Hitam } & \text { A. niger } \\ \text { AS29 } & - & - \\ \text { AS30 } & - & - \\ \text { AS31 } & \text { Hijau pekat } & \text { A. fumigatus } \\ \text { AS32 } & \text { Hijau pekat } & \text { A. fumigatus } \\ \text { AS33 } & \text { Hijau pekat } & \text { A. fumigatus } \\ \text { AS34 } & - & - \\ \text { AS35 } & \text { Hijau pekat } & \text { A. fumigatus }\end{array}$

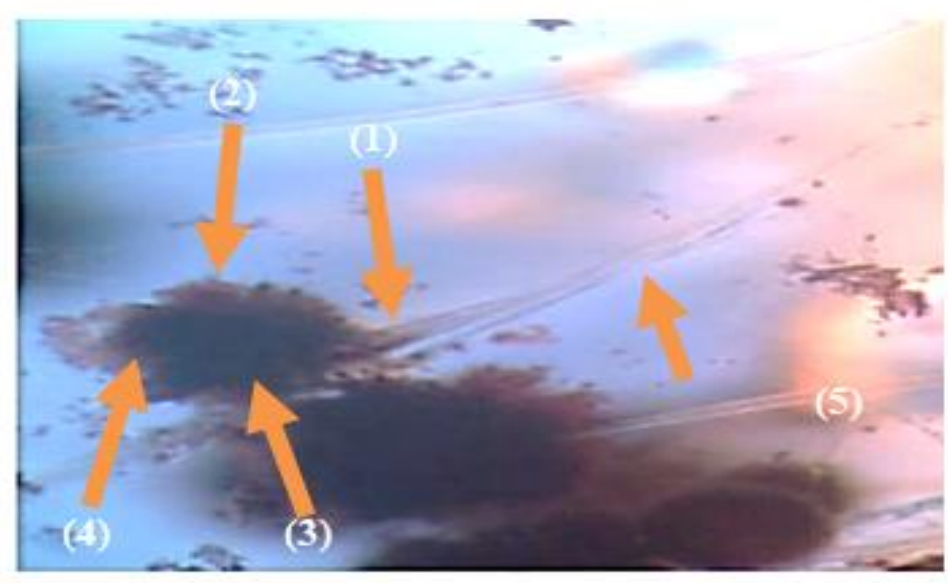

Gambar 3 Mikroskopis Aspergillus sp. dengan menggunakan pewarnaan Lactophenol Cotton Blue (LCB) pembesaran 400x. (1) Konidiofor, (2) Konidia, (3) Vesikel, (4) Fialid, (5) Septa

\section{DAFTAR PUSTAKA}

Ade FY. 2013. Isolasi dan identifikasi jamur-jamur pendegdradasi amilosa pada empelur tanaman sagu (Metroxylon sagu Rottb.). Jurnal IImiah Edu Research. 2(1): 27-34.

Akoso BD. 1998. Kesehatan Unggas: Panduan Bagi Petugas Teknis, Penyuluh dan Peternak. Kaninus, Yogyakarta.

Beernaert LA, Pasmans F, Waeyenberghe LV, Haesebrouck F, Martel. 2010. Aspergillus infection in birds: a review. Avian Pathology. 39(5): 325-331.

Brooks GF, Carroll KC, Butel JS, Morse SA, Mietzner TA. 2013. Mikrobiologi Kedokteraan Jawets, Melnick \& Adelberg's Ed.25. Jakarta (ID): Penerbit Buku Kedokteran EGC.

Destia M, Sudrajat D, Dihansih E. 2017. Pengaruh rasio panjang dan lebar kandang terhadap produktivitas burung puyuh (Cortunix cortunix japonica) periode produksi. Jurnal Peternakan Nusantara: 3(2): 57-63.

Fathoni R, Radiastuti N. Wijayanti F. 2007. Identifikasi jenis cendawan pada kelelawar (Ordo Chiroptra) di Kota Tangerang Selatan. Jurnal Mikologi Indonesia. 1(1): 28-37.

Gandi NLPG, Getas IW, Jannah M. 2019. Studi jamur Aspergillus fumigatus penyebab aspergillosis dipasar Cakranegara kota Mataram dengan media Pertumbuhan Potato Dextrose Agar (PDA). Jurnalis Analisis Medika Bio Sains. 6(1).

Gandjar L, Syamsuridzal W, Oetari A. 2006. Mikologi Dasar dan Terapan. Jakarta (ID): Yayasan Obor Indonesia.

Gholib D, Tarmudji. 2005. Kasus aspergillosis granuloma pada paru-paru burung Emu (Dramacius novaehollandies). Jurnal Mikologi Kedokteran Indonesia. 6(1):38-40. 
Hasanah U. 2017. Mengenal aspergillosis, infeksi jamur genus Aspergillus. Jurnal Keluarga Sehat Sejahtera. 15(30): 74-86.

Krishnan S, Manavathu EK, Chandrasekar, PH. 2009. Aspergillus flavus: an emerging non-fumigatus Aspergillus species of significance. Mycoses. 52: 206-222.

Maryam R. 2006. Pengendalian terpadu kontaminasi mototoksin. Balai Penelitian Veteriner. 16(1): 21-30.

Naim N. 2016. Pemanfaatan bekatul sebagai media alternatif untuk pertumbuhan Aspergillus sp. Media Analisis Kesehatan. 7(2): 1-6.

Natasha. 2018. Aspergillosis pada puyuh (Cortunix japonica) [skripsi]. Banda Aceh (ID): Fakultas Kedokteran Hewan, Universitas Syiah Kuala.

Nyongesa BW, Okoth, S, Ayugi V. 2015. Identification key for Aspergillus species isolated from maize and soil of nandi cowty, Kenya. Scientific Research Publishing. 5(5): 205-229.

Praja RN, Aditya Y. 2017. Isolasi dan identifikasi Aspergillus spp. pada paru-paru ayam kampung yang dijual di pasar Banyuwangi. Jurnal Medik Veteriner. 1(1): 6-11.
Saminan. 2016. Efek obstruksi pada saluran pernapasan terhadap daya kembang paru. Jurnal Kedokteran Syiah Kuala. 16(1): 34-39.

Sugui JA, Kwon-Chung KJ, Juvadi PR, Latge JP, Steinbach WJ. 2015. Aspergillus fumigatus and related species. Cold Spring Harb. Perspect Med. 5(10).

Susilorini TE. 2007. Budidaya Ternak Potensial. Jakarta (ID): Penebar Swadaya.

Throne SSJ, Sander, JE, Brown T, Lobsinger CM, Thayer SG, Martinez A. 2003. Disseminated myosis in layer cockerels and pullets. Avian Diseases. 47 (1): 229-233.

Tokarzewski S, Ziolkowska G, Looszynski W, Nozdryn PZ. 2007. Aspergillus fumigatus infection in pigeon flock. Bulletin of the Veterinary Institute in Pulawy. 51(4): 563-567.

Wangge ESA, Suprapta GNA, Wirya. 2012. Isolasi dan identifikasi jamur penghasil mikotoksin pada biji kakao kering yang dihasilkan di Flores. J. Agric. Sci. and Biotechnol. 1(1):39-47.

Wheindrata HS. 2014. Panduan Lengkap Beternak Burung Puyuh Petelur. Yogyakarta (ID): Lily Publisher. 